\title{
ECRIF Framework System
}

\author{
Irfan Tosuncuoglu \\ Correspondence: Irfan Tosuncuoglu, Karabuk University, Faculty of Letters, English Language and Literature \\ Department, Karabuk, 78050, Turkey.
}

Received: January 23, 2017

doi:10.11114/jets.v5i3.2175

\author{
Accepted: February 8, $2017 \quad$ Online Published: February 9, 2017 \\ URL: http://dx.doi.org/10.11114/jets.v5i3.2175
}

\begin{abstract}
English is an international language-it is already known by everybody. There have been a lot of ideas and discussions about foreign language learning. And nowadays we have met the framework of ECRIF. It is shortly a framework to help students learn new language and skills so that they can use them fluently and, it has to do with adopting a more learning-centered model of learning the lessons that the teacher conducted. If we analyze; E means encounter, $\mathrm{C}$ means clarity, R means remember, I means internalize, F means fluency. Consequently, we can infer by means of ECRIF framework does not how the lesson to be conducted, unlike it gives an idea to the teacher how the learning process is going on, and they can have an idea that what do the students think during the lesson. In this article it is tried to be developed a viewpoint in English teaching within the context of ECRIF.
\end{abstract}

Keywords: learning, clarity, fluency, language, perception, framework

\section{Introduction}

Language is essential to communicate, express our thoughts and feelings, and understand the world. The spread of English began with the British colonization process and reached its highest point through the role of the United States of America as the dominant economic power in the world at present (Pennycook, 1995; Phillipson, 1992). Nowadays, English is used as a "lingua franca" which is widely adopted for communication between two speakers whose native languages are different from each other and where one or both speakers are using that language as a second language (Harmer, 2001).

For the linguist Edward Sapir, "language is not only a vehicle for the expression of thoughts, perceptions, sentiment and values characteristic of a community; it also represents a fundamental expression of social identity." (Spair, 1921) The first thing that comes to mind for international communication is English. Nowadays, the necessity of intergovernmental communication is getting increasingly bigger and bigger.

English Language is spoken as a communication language among a lot of countries. English is a key language in the world. It plays an important role in human life. So far, theorists have been assuming that mistakes of learning depended on students but nowadays some scientist have been giving some responsibilities on teachers to some extent.

Assessment is needed by different authorities such as provosts, teachers, students and their parents about to what extent learners grasped the knowledge. According to Kirmizi (2016), performance assessments in English instruction have been particularly examined by international researchers. Kim (2004) researched main matters to consider in task based performance assessment. She emphasized the importance of purpose, the authenticity of assignments and development of scoring criteria if fair and valid tests are to be created for learners. Likewise Hudson \&Brown (1998), compared and contrasted alternatives in language assessments and ended with a discussion on using a variety of assessments considering curricula, feedback and decision-making. In their study, they emphasized the role of teachers as decision makers and supervisors in assessment. Administrators regularly demands assessments to judge if the planned programs are working properly and to understand if students are making progress in their courses. If the result of the assessment is not satisfactory, it is an indication that it is necessary to change and replan the program for a better achievement of the objectives.

Language acquisition starts at the time a person was born. Language acquisition is very similar to the process children use in acquiring first and second languages. It requires that meaningful interaction in the target language in which speakers is concerned not with the form of their phonations but with the messages they are communicating and understanding (Brown, and Hanlon, 1970). When learners want to learn a language as a second language, this 
resembles that how an infant acquire his first language. Both of them try to say something meaningful and they learn basic grammar rules like prepositions.

A person who is constantly researching and has self-improvement characteristics wants to learn new things and meet the age requirements. Therefore, they want to acquire a new language, especially English as an international language. This is called as Foreign Language acquisition. Learners can acquire a lot of different languages. Not only FLA means second language for learners but also it can refers third, fourth, fifth languages, all of them are called as second language acquisition. It refers that learning a language after native language. The Longman Dictionary of Contemporary English defines English as a Foreign Language as the teaching of English to people whose first language is not English, and who do not live in an English Speaking country. (Longman, 2009) There are a lot of ways to learn a language as a foreign language. It can learn in a formal way such as in a classroom and informal way such as target country, watching television or series, listening to music or reading foreign newspapers. A person can improve oneself with these ways.

In this age, English is being seen as an international language and it is being taught in every school term even in preschool education. Government consider learning English as significant because of this English is being taught as a Foreign language by teachers. The English learners are in contact with the target language through their normal daily routines. Also, motivation as addition important factor of Language learning and it is a significant factor of language according to Gardner and Lambert (Gardner and Lambert, 1972). If learners want to learn exactly in a good mood, they can be successful in this way all-around. There have been a lot of ideas about Language learning effectively, we can see nowadays ECRIF framework system.

\section{Meaning of ECRIF}

The ECRIF is a framework system of a way of looking at how students learn a language. By means of this framework system the teachers can understand how they do the effective foreign language learning, the object of this method is to supply what to do or what not to do, and in which style students can learn better. By means of ECRIF, teachers can notice that to what extent the teaching is fruitful and they observe the approach of the students to the target language.

\section{Usage of ECRIF}

The main idea of ECRIF framework is to be focused on the learning process, and teachers can check that by means of which activities students can learn better. By means of this, teacher can plan the classroom activities. And ECRIF can be applied in the following step. ${ }^{1}$

1. to plan lessons and adapt course book materials (reflecting for action)

2. to assess where students are in their learning process during a lesson (reflecting in action)

3. to reflect on student learning after a lesson (reflecting on action)

According to our investigation we came to conclusion that the ECRIF is not a direct and common way of teaching language. First of all students should practise the language before they learn it. They go back to their peers or teacher to clear something that is not exactly understood, and then they can return again to drill or practice fluency. Before the subjects meet a new meaning or use of the same structure which again leads them to clarify, remember, etc., students have grasped the meaning of a target information

What does ECRIF include? ${ }^{2}$

Storytelling

Realia

Role-plays

Pictures

Recordings

Matching

Categorizing

Brainstorming

\footnotetext{
${ }^{1} \mathrm{http} / / / \mathrm{www} . e c r i f . c o m /$

${ }^{2}$ https://prezi.com/shsh_pc9ony7/ecrif-a-language-learning-framework/
} 
Now let's analyze, what the word E C R I F stand for.

Encounter

The goal of the ECRIF framework is to introduce students with a new language and knowledge in order them to use it fluently and right for communication inside and mainly outside the classroom.

Matching activity

Identify correct and incorrect answers

Ask CCQs (Concept Checking Questions)

Clarify contains;

Drilling

Gap fill

Information gap

Searches

Scrambled words

Guessing games

Matching

Reading scripts

Dialogues

Remember includes;

Guessing games

Information gaps

Storytelling/ role play

Short answer activities

Project structured discussions

Card games

Internalize stands for;

Guessing games

Fluency lines

Debates

Role play

Information gap

Discussions

Fluency, fluency is interconnected with aforementioned activities.

ECRIF is that the Teacher prepares the stages of a lesson based upon student- centered learning. It can be like that, a teacher prefers to begin lessons with fluency practicing, or start with phonetics exercises based on the evaluation of learner production in the grasping or fluency stage of the lesson.

The ECRIF framework does not mean a "right" or "the best way" way to conduct or any specific technique, style or methodology. Unlike, it prefers a much more learning-centered way of thinking about the lessons that the teachers have already taught. We can understand the lessons from a learner's viewpoint, by means of this way, and make regulations if it is needed, to the lessons in order to conduct lessons.

\section{Student-centered Teaching through ECRIF}

The ECRIF framework wants the teacher shift their thinking and imaginations so that they can accept or agree the levels of the students. Let's imagine that, “The students met some new vocabulary that they don't know as they studied pictures of professions. The students can clarify the word for that profession by first hearing the other students in the class say the professions, hearing the teacher say it, and seeing it written on the blackboard written form." The encounter stage of learning is the first time a learner meets new information or a new material or book. The Encounter 
will be often prefaced by means of activating the learner's background knowledge, or noticing what they have already known. It includes some items: paying attention, noticing that there should be something to be learned and then to be understood what it that is being learned. The student studies to realize what kind of the grammar, vocabulary, or skill it is and what it demands. Clarifying is the process that is realized inner part of the student; when the student tries to define the form, meaning, use of a vocabulary. For instance, pronunciation or meaning of a word. Definitely, teachers of course give a hand to the students in checking, clarifying, and evaluating learners' perception understanding of the target knowledge. The teachers do perception or comprehension check, one way of ways, is with comprehension checking questions, or we can shortly say CCQ's.

It can be said that, this is the first step in conveying a new material to the student's memory. It is usually determined by means of repetition, drilling, and denoting backward knowledge to supporting materials such as realias or cues and books. As soon as a student grasps information, it is conveyed to long-term memory. Before students refer to materials or information in order to remember, material or information should be grasped, because they can use the information that is stored in their long term memory. After that the following practice is needed the students to grasp new knowledge or information. All the same, practicing is different from the remembering phase in that it is at present time the students will feel themselves independent and they feel themselves at ease, and they can be in need of outside support less.

In this step of student learning, concerning with their present understanding and perception of the material and information, the learners can use new material and information fluently. In this phase the students achieve knowledge freely and produce the target language creatively.

Concerning with the teaching freely we Freeman and Lier says ${ }^{3}$, under the heading of "Becoming a Learner of a Teaching", as a professional learner of teaching, when you become more conscious of your options, you see a fuller range of opportunities in each classroom situation, and your decisions reflect those possibilities. You become a decision-maker, and your decisions are informed by a close and careful examination of what happens when you make them. While teaching does not make learning happen, it certainly does influence it. We believe that you will develop as a teacher as you make decisions and assess how these decisions work for your learners in your classroom.

\section{Conclusion}

In conclusion we can infer by means of ECRIF framework does not how the lesson to be conducted, unlike it gives an idea to the teacher how the learning process is going on, and they can have an idea that what do the students think during the lesson. We can say that the teachers' aim is to provide the students with an excellent learning activities. Students can be willing to have a positive attitude and good learning habit toward English. Students with a positive attitude, thus, using so called methods and techniques keeping on effectual learning habit can lead to an efficient learning.

Another equally important point to consider is that the students do not learn from the materials only and they are motivated by the teacher study cooperatively. By means of this they can be excellent individuals in the future. This might be because of the type of the attitudes that the teacher provide the students with. However, the teacher can give the students the feeling of studying cooperatively sometimes as a group not as an individual, which created a team soul among them. Traditional teaching techniques do not provide the students with the awareness that they need to share and learn the new knowledge they have perceived from their errors or mistakes. Thus, the students can feel more productive and safe while learning the target language. Supplying them with the useful materials, prompts, cues, realias, etc., will increase the success of the students because they will easily concentrate on learning thanks to the ECRIF.

\section{References}

Brown, R., \& Hanlon, C. (1970). In JR. Hayes(ed.) Cognition and the Development of Language, New York.

Gardner, R.C., \& Lambert, W. E. (1972) .Attitudes and Motivation in Second-Language Learning. Rowley, Mass: Newbury House Publishers.

Harmer, J. (2001). The practice of English Language Teaching. The World of English. (pp.1-10). Malaysia: Pearson.

Kim, H. (2004). Task-Based Performance Assessment for Teachers: Key issues to consider. Columbia University Working Papers in TESOL and Applied Linguistics, 4(2), 1-5.

Kirmizi, O., \& Komec, F. (2016). An Investigation of Performance-Based Assessment at High Schools. Üniversitepark Bülten, 5(1-2), 53-65. https://doi.org/10.22521/unibulletin.2016.512.5

Levenston, E. A. (1979). Second language acquisition: Issues and problems. Inter-language Studies Bulletin, 147-160.

\footnotetext{
${ }^{3}$ http://www.prolinguaassociates.com/Understanding_Teaching_Through_Learning/UTTL\%20Introduction.pdf
} 
Longman Dictionary (2009). The Longman Dictionary of Contemporary English. Pearson Education Limited, Essex, England.

Pennycook A. The Cultural Politics of English as an International Language by (1994). Harlow, Essex, UK: Longman Group Limited

Phillipson, R. (1992). Linguistic Imperialism. Oxford: Oxford University Press.

Popham, W. J. (2008). Standards-based education: Two wrongs don't make a right. The nature and limits of standards-based reform and assessment, 15-25.

Sapir, E. (1921). Language: An introduction to study of speech. New York: Harcourt, Brace and Company.

Schmitt, N. (2010). Research and Practice in Applied Linguistics. C. N. Candlin, \& D. R. Hall (Eds.), Researching Vocabulary. Macmillan.

http://www.collinsdictionary.com/, retrieved on 4 August 2015

https://prezi.com/shsh_pc9ony7/ecrif-a-language-learning-framework/, retrieved on 6 October 2015.

http://seeinglearninghappen.weebly.com/reflections-on-ecrif.html, retrieved on 17 November 2015.

http://www.ecrif.com/ retrieved on 2 December 2016.

http://www.prolinguaassociates.com/Understanding_Teaching_Through_Learning/UTTL\%20Introduction.pdf, retrieved on 03 January 2017.

\section{Copyrights}

Copyright for this article is retained by the author(s), with first publication rights granted to the journal.

This is an open-access article distributed under the terms and conditions of the Creative Commons Attribution license which permits unrestricted use, distribution, and reproduction in any medium, provided the original work is properly cited. 